\title{
The distribution of Culex mosquitoes in Coimbatore, Tamil Nadu, India
}

\author{
A. Naresh Kumar, ${ }^{1}$ K. Murugan, ${ }^{2}$ C. Thomas Vincent, ${ }^{3}$ P. Madhiyazhagan, ${ }^{2}$ T. Nataraj, ${ }^{2}$ \\ K. Shobana ${ }^{4}$ \\ 1Department of Zoology, Periyar University, Salem; ${ }^{2}$ Department of Zoology, Bharathiar \\ University, Coimbatore; ${ }^{3}$ Department of Public Health and Preventive Medicine, Zonal \\ Entomological Team, Govt. of Tamil Nadu, Coimbatore; ${ }^{4}$ Sri GVG Visalakshi College for \\ Women, Udumalpet, Tamil Nadu, India
}

\begin{abstract}
Lymphatic filariasis is an infection with the filarial worms, Wuchereria bancrofti, Brugia malayi and B. timori. These parasites are transmitted to humans through the bite of an infected Culex mosquito and develop into adult worms in the lymphatic vessels, causing severe damage and swelling (lymphoedema). Mosquito control, in view of their medical as well as economical importance, assumes global importance. Geographic information system (GIS) is a powerful tool to analyse the distribution of mosquitoes and their relationship to different environmental factors, and can substantially improve our ability to quantify the impacts of demographic, climatic and ecological changes in vector distribution. In the present study Culex quinquefasciatus, Culex tritaeniorhynchus and Culex gelidus were recorded in the study area. Few other factors such as larval mosquito density, number of breeding sites, human population, etc. were also analysed for its impact on the distribution of Culex mosquitoes. Distribution of Culex in the present study affirmed that $C$. quinquefasciatus is predominant in the entire focal area, which explains the behavioural response and
\end{abstract} Correspondence: Arjunan Naresh Kumar, Department of Zoology, Periyar
University, Selem - 636011, India.

E-mail: nareshphd@gmail.com

Key words: ArcGIS; Culex quinquefasciatus; Culex gelidus; Culex tritaeniorhynchus; larval habitats; mapping.

Acknowledgements: the authors are extremely indebted to convey their bouquet of thanks to Council of Scientific \& Industrial Research (CSIR), Human Resource Development Group, CSIR Complex, Library Avenue, Pusa, New Delhi 110 012, India for providing Research Associateship (RA) and funds (Award letter No. 09/472 (0161) /2012 - EMR-I, dated: 29/03/2012) to run the project successfully.

Received for publication: 10 July 2014.

Revision received: 3 October 2014.

Accepted for publication: 3 October 2014.

(C) Copyright A. Naresh Kumar et al., 2015

Licensee PAGEPress, Italy

Journal of Entomological and Acarological Research 2015; 47:4565

doi:10.4081/jear.2015.4565

This article is distributed under the terms of the Creative Commons Attribution Noncommercial License (by-nc 3.0) which permits any noncommercial use, distribution, and reproduction in any medium, provided the original author(s) and source are credited. capability of the species in varied zones. Information gathered from this study is being used to construct a GIS-based mapping system for distribution of Culex mosquitoes in the Coimbatore District, Tamil Nadu, India.

\section{Introduction}

Filariasis is the common term for a group of diseases caused by parasitic nematodes transmitted through vectors. The most widespread lymphatic filariasis infection is due to Wuchereria bancrofti Cobbold, 1877 (90\%) and the remaining infection by Brugia malayi Brug, 1927 and they are commonly called Bancroftian and Brugian filariasis respectively. The major vector of $W$. bancrofti is mosquito of the genus Culex (World Health Organisation, 2013).

An estimated 120 million people in tropical and subtropical areas of the world are infected with lymphatic filariasis; of these, almost 25 million men have genital disease (most commonly hydrocele) and almost 15 million, mostly women, have lymphoedema or elephantiasis of the leg. Approximately $66 \%$ of those at risk of infection live in the South-East Asia Region and 33\% in the African Region (World Health Organisation, 2013).

Japanese encephalitis (JE), an infectious disease caused by viral pathogen and transmitted by mosquito, is responsible for millions of deaths worldwide. The JE virus was been identified in 16 mosquito species, in which 10 are from Culex, three from Anopheles, and three from Mansonia mosquitoes (Murty et al., 2010). Culex genus is quite diverse, with well over a thousand species in which several species serve as vectors of important diseases. The adult mosquito can measure from 4-10 mm and morphologically has the three body parts common to insects: head, thorax, and abdomen. As a fly, it has a pair of wings. Development in mosquitoes, increase in mosquito population and breeding sites are related to many other environmental and anthropogenic factors. Temperature and precipitation are the proxy variables more responsible of the density level of mosquitoes (Gingrich et al., 1992; Lin \& Lu, 1995).

The environmental and eco-climatic factors are assisting in enhancing the breeding of the mosquitoes. The Culex species are quite adaptable to fluctuating environmental conditions requiring suitable control measures in both rural and urban areas. Vector control program in developing countries like India is difficult because of lacking in awareness of the diseases transmitted through mosquitoes. The development of mosquitoes resistant to synthetic chemicals, increase in human population which lead to an increase in hosts for mosquitoes, global warming and other demographic conditions are the main reasons for making vector control a challenging issue.

In this context geographic information system (GIS) is helpful in 
epidemiological settings: for data collection, management, analysis, etc. Benefits of using remote sensing in the identification of mosquito breeding habitats were reported by many researchers (Linthicum et al., 1987; Pope et al., 1992; Wood et al., 1992; Dale \& Morris, 1996; Thomson et al., 1996; Masuoka et al., 2003). Potential larval habitats of the mosquito Culex tarsalis (Coquillett, 1896), implicated as a primary vector of West Nile virus in Wyoming, were identified using integrated remote sensing and GIS analyses (Zou et al., 2006).

The aim of the present research is to picture and map out the distribution of filarial vector in the Coimbatore District, Tamil Nadu, India using GIS. The additional environmental and demographical factors found along with the species distribution were most responsible for the distribution of species. The maps produced were expected to improve the effectiveness of vector control and to reduce vector control costs by expediting the time required to locate, verify, and treat larval developmental sites. The present work demonstrates the manifold applications of GIS in particular the production of distribution and forecasting maps applied to an important public health problem.

\section{Materials and methods}

\section{Study area}

The study area (Coimbatore District) lie between latitudes $11^{\circ} 6$, $12.39^{\prime \prime} \mathrm{N}$ and $11^{\circ} 0{ }^{\prime} 45^{\prime \prime} \mathrm{N}$ and longitudes $76^{\circ} 58^{\prime} 17^{\prime \prime} \mathrm{E}$ and $77^{\circ} 5^{\prime} 59.31^{\prime \prime}$ E. Coimbatore District consists of 295 Revenue Villages distributed among six Taluks within two Revenue Divisions (Coimbatore and Pollachi). Of the two Revenue Divisions, Coimbatore is mainly industrial and Pollachi is agricultural.

Seventeen Revenue Villages [hereafter termed village(s) (Figure 1)] from Coimbatore and Pollachi Revenue Divisions were selected for this study [Chettipalayam ( $77^{\circ} 1^{\prime} 24.16^{\prime \prime} \mathrm{E}-10^{\circ} 54^{\prime} 51.82$ ” N), Ettimadai $\left(76^{\circ}\right.$ 53 ' 2.73” E - $10^{\circ} 52$ ' 58.82” N), Idikarai ( $76^{\circ} 58^{\prime} 26.41^{\prime \prime}$ E - $11^{\circ} 7^{\prime} 47.43^{\prime \prime}$ $\mathrm{N})$, Kalapatti $\left(77^{\circ} 2\right.$ ' $\left.31.25^{\prime \prime} \mathrm{E}-11^{\circ} 3^{\prime} 45.03^{\prime \prime} \mathrm{N}\right)$, Kuniamuthur $\left(76^{\circ} 56^{\prime}\right.$ 45.19 ” E - $10^{\circ} 56^{\prime} 55.41$ ” N), Kurichi ( $76^{\circ} 58^{\prime} 24.07$ ” E - $10^{\circ} 56^{\prime} 34.22$ ” N), Madukkarai ( $76^{\circ} 56^{\prime} 41.67^{\prime \prime} \mathrm{E}-10^{\circ} 53$ ' $\left.44.73^{\prime \prime} \mathrm{N}\right)$, Mallumichempatty $\left(77^{\circ}\right.$ 0' $\left.52.38^{\prime \prime} \mathrm{E}-10^{\circ} 57^{\prime} 55.44^{\prime \prime} \mathrm{N}\right)$, Narasimhanaichenpalayam $\left(76^{\circ} 56^{\prime}\right.$ 58.54 " E - $11^{\circ} 7^{\prime} 22.55$ ” N), Othakalmandapam (76 $59^{\circ} 31.16^{\prime \prime} \mathrm{E}-10^{\circ} 52^{\prime}$ 16.45 ” N), Periyanaichenpalayam (76 ${ }^{\circ} 57^{\prime} 48.70^{\prime \prime}$ E - $\left.11^{\circ} 9^{\prime} 47.41^{\prime \prime} \mathrm{N}\right)$,

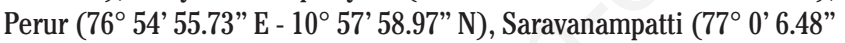

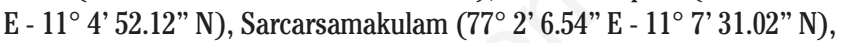
Thondamuthur ( $76^{\circ} 49^{\prime} 52.05$ " E - $11^{\circ} 0$ ' $\left.27.28^{\prime} \mathrm{N}\right)$, Thudiyalur $\left(76^{\circ} 56^{\prime}\right.$ 2.82 " E - $11^{\circ} 4$ ' $\left.23.87^{\prime \prime} \mathrm{N}\right)$, Veerapandi $\left(76^{\circ} 58^{\prime} 15.18^{\prime \prime}\right.$ E - $11^{\circ} 11^{\prime} 25.94$ " $\mathrm{N})$ ]. Each village has a history of mosquito-borne disease.

Each village was considered a single study plot and was visited on several occasions for data collection purposes in collaboration with the Coimbatore District Public Health Department. The boundaries of each village/study plot were determined using the global positioning system. Each site was geo-referenced, its size and the presence of mosquito larvae ascertained, and data entered into a dBase/DBF files of ArcGIS. Pictorial analysis of variations in mosquito distribution was made using serial editing techniques. The parameters characterized according to this process were evaluated using real-time imagery and considered for inclusion as classification variables in a descriptive model of mosquito distribution.

\section{Classification of variables}

Demographic factors such as human population size and percentage of education (\% of people reached their high school level) were collected. In our view, each of these variables may be related to the creation and availability of mosquito development sites. To test this hypothesis for human population density, we evaluated the relationship between the numbers of humans in a study plot and the availability of mosquito development sites.

Land use factors facilitate geographic differentiation of study plots on the basis of variables associated with (human) occupation and the topography and physiography of the land. The study area was classified as agricultural, industrial, or agro-industrial depending on geographical attributes that included land use, arability, the number and type(s) of industries, and the proportion of the human population engaged in each type of industry. Developmental sites of Culex larvae taken in account are artificial water containers, and storm water and sewage systems.

Biological factors include some of the quantitative and qualitative attributes of natural mosquito populations that have been determined by human observation and measurement. The simplest of these comprises knowledge of mosquito presence/absence and population density. When larvae were present in a habitat, their density was assessed by capturing those at the water surface in a $350 \mu$-mesh hand-held dip net. The number of samples taken using this technique depended on the surface area of the habitat and ranged between 5 and 60 per habitat (no two samples of larvae were taken from the same location in a habitat).

Mosquito larvae were collected in July (when mosquito populations in the Coimbatore District are at their highest level of the year) from mosquito sites using a $350 \mu$-mesh hand-held dip net. The collected larvae were placed in plastic containers with water from the collection site. The containers were closed, placed in a cooler, and returned to the laboratory where some of the larvae were preserved in $80 \%$ ethanol (in $\mathrm{H}_{2} \mathrm{O}$ ) for species identification. The remaining larvae were reared to adults and used as voucher specimens (the specimen retained for future reference) for the study. Species identifications all were verified by personnel at the Department of Public Health, Coimbatore, Tamil Nadu, India.

\section{Data analysis}

Feature class data (collection of geographic features that allows homogeneous features to be grouped into a single unit for data storage purposes) for human population-related parameters were acquired from records maintained by the Department of Public Health, Coimbatore District. Environmental data were obtained from the Indian Meteorological Department in Coimbatore. Biological data were acquired by direct observation in field sites using the methods and techniques described above. Georeferencing of field coordinates with a Coimbatore District, Revenue Village boundary map (purchased from the Department of Survey and Land Records, Coimbatore, Tamil Nadu, India) was performed using ArcMap. Spatial analyses were made using ArcGIS (9.1).

\section{Results}

The study area includes 17 villages occupied by both agricultural lands and industries. Human population density of the study plot is shown in Figure 2. Population density was classified into 5 categories using natural breaks data classification technique. Differentiation of the classes is shown by a range of colours. Population range in the study area was between 6251 to $76,794 / \mathrm{sq}$. $\mathrm{km}$. Idikarai a semi agricultural village recorded the lowest population of $6251 / \mathrm{sq}$. km. Ettimadai, Mallumichempatty, Othakalmandapam, Perur, Sarcarsamakulam and Thondamuthur recorded population range between 6252 to $9681 / \mathrm{sq}$. $\mathrm{km}$. Veerapandi and Narasimhanaichenpalayam recorded population range between 9682 to $12,141 / \mathrm{sq}$. km. Chettipalayam, Madukkarai, Thudiyalur, Kalapatti, Periyanaichenpalayam and Saravanampatti recorded population range between 12,142 to $25,733 / \mathrm{sq}$. $\mathrm{km}$. Kuniamuthur and Kurichi recorded the highest population range between 25,734 to $76,794 / \mathrm{sq}$. $\mathrm{km}$. 
Figure 3 shows the industrial and non-industrial plots of the study area, which also groups under the factor responsible for distribution and development of mosquitoes and their breeding habitats. Ettimadai, Mallumichempatty, Othakalmandapam, Perur and Sarcarsamakulam are non-industrial plots and Kalapatti, Periyanaichenpalayam,
Saravanampatti, Chettipalayam, Idikarai, Madukkarai, Narasimhanaichenpalayam, Thudiyalur, Veerapandi, Thondamuthur, Kuniamuthur and Kurichi are industrial plots which are responsible for toxic chemicals released from industries, leading to increase in green house gases, global warming and vector population.

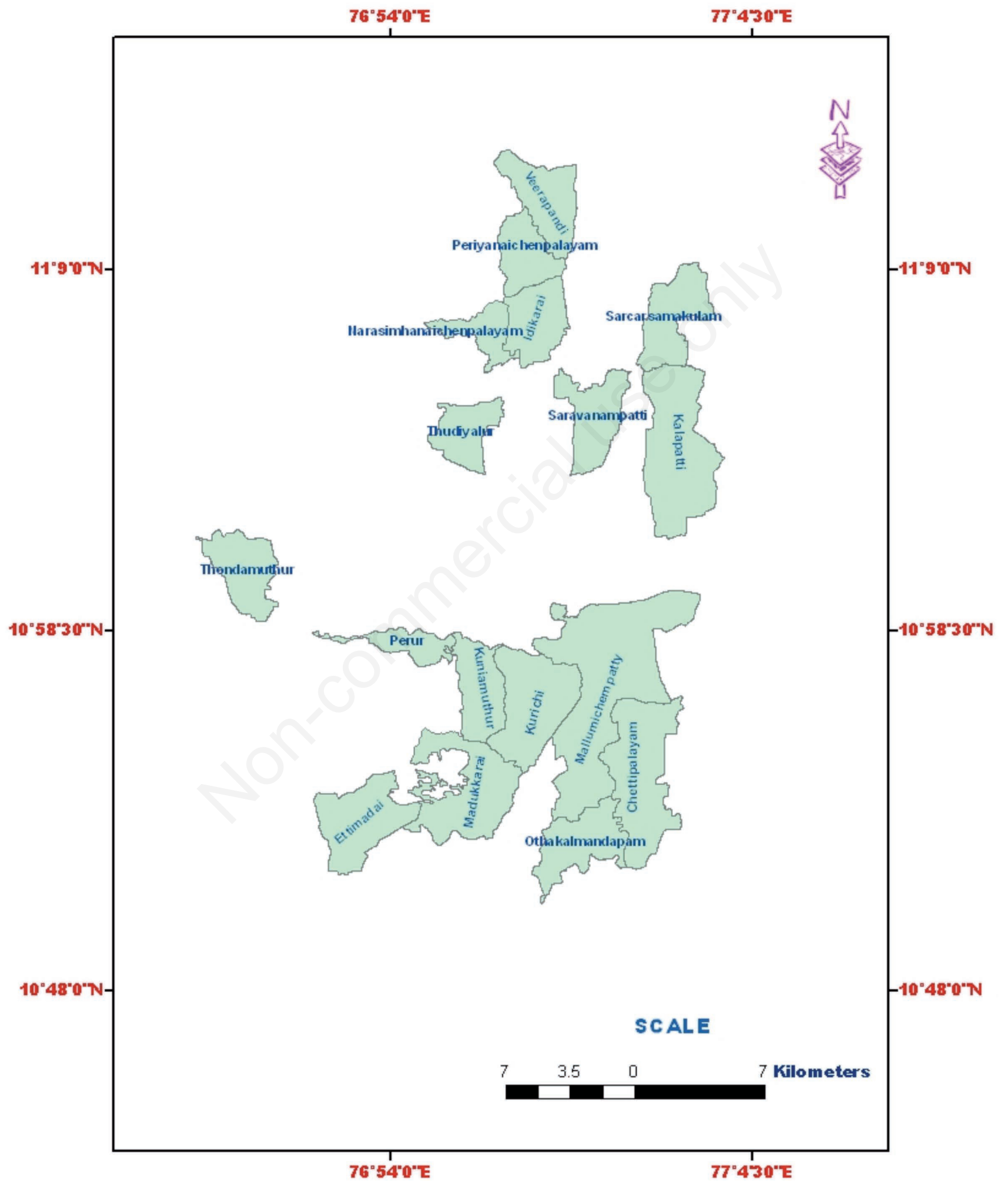

Figure 1. The study area. 
Percentage of education of the study area is shown in Figure 4. In the study area percentage of education was ranging between 56 to $80 \% / \mathrm{sq}$. km. Ettimadai recorded the lowest percentage of education (56\%/sq. km). Percent education in Perur, Sarcarsamakulam and Thondamuthur was ranging between 57 to $68 \% / \mathrm{sq}$. km. Education in Kalapatti, Madukkarai, Mallumichempatty, Othakalmandapam and Veerapandi was ranging between 69 to $72 \% / \mathrm{sq}$. km. Percentage of education in Chettipalayam, Kuniamuthur and Thudiyalur was between 73 to $75 \% / \mathrm{sq}$. km. Idikarai, Kurichi, Narasimhanaichenpalayam and Periyanaichenpalayam recorded the highest percentage of education (76 to $80 \% / \mathrm{sq}$. km).

Figure 5 shows the number of mosquito breeding sites in the study area. Mosquito breeding sites included all permanent and temporary sources of mosquito breeding. Ettimadai, Idikarai, Perur and Sarcarsamakulam recorded lowest number of mosquito breeding sites (14,238 to $18,105 / \mathrm{sq}$. km). Mallumichempatty, Othakalmandapam, Saravanampatti and Thondamuthur recorded breeding sites ranging between 18,106 to 21,786/sq. km. Chettipalayam, Narasimhana-ichenpalayam, Periyanaichenpalayam and Veerapandi recorded 21,787 to 27,157 numbers of breeding sites. A number of 27,158 to 40,133 of breeding sites were recorded in Idikarai, Kalapatti and Thudiyalur. Kuniamuthur and Kurichi recorded the highest number of mosquito breeding sites (40,134 to $92,146 / \mathrm{sq}$. km).

Density of mosquitoes in the breeding sites of the study area was estimated by the dipping method and presented in Figure 6 and Table 1. Perur registered around 2 mosquitoes/dip, which was the lowest record of mosquito density in the study area. Idikarai and Madukkarai registered around 3 mosquitoes/dip; Ettimadai, Mallumichempatty and Thondamuthur registered around 4 mosquitoes/dip; Chettipalayam, Othakalmandapam, Kalapatti, Kuniamuthur, Narasimhanaichenpalayam, Sarcarsamakulam and Veerapandi registered around 5 mosquitoes/dip; Kurichi, Periyanaichenpalayam, Saravanampatti and Thudiyalur recorded around 6 mosquitoes/dip.

Distribution of Culex spp. in the study plot is mapped out and presented in Figure 7. Culex quinquefasciatus, Culex tritaeniorhynchus and

Table 1. Number of immature mosquitoes recorded in the study area.

\begin{tabular}{lcc} 
Sample No. & Name of the place & Number of larvae/dip \\
1 & Chettipalayam & 4.6 \\
2 & Ettimadai & 4.1 \\
\hline 3 & Idikarai & 3.3 \\
4 & Kalapatti & 5.2 \\
\hline 5 & Kuniamuthur & 5.2 \\
6 & Kurichi & 5.9 \\
\hline 7 & Madukkarai & 2.5 \\
8 & Mallumichempatty & 3.7 \\
\hline 9 & Narasimhanaichenpalayam & 5.1 \\
10 & Othakalmandapam & 4.8 \\
\hline 11 & Periyanaichenpalayam & 5.6 \\
12 & Perur & 2.1 \\
\hline 13 & Saravanampatti & 5.8 \\
14 & Sarcarsamakulam & 5.1 \\
\hline 15 & Thondamuthur & 4.3 \\
16 & Thudiyalur & 5.5 \\
\hline 17 & Veerapandi & 5.1 \\
\hline
\end{tabular}

Culex gelidus were the three species recorded in the study area. Chettipalayam, Kalapatti, Kuniamuthur, Kurichi, Periyanaichenpalayam and Narasimhanaichenpalayam recorded C. quinquefasciatus; Sarcarsamakulam recorded $C$. quinquefasciatus and $C$. gelidus; Idikarai, Saravanampatti, Thudiyalur, Veerapandi, Ettimadai, Madukkarai, Mallumichempatty, Othakalmandapam, Perur, and Thondamuthur recorded $C$. quinquefasciatus and $C$. tritaeniorhynchus.

Figure 8 shows the comparison of breeding sites and human population density. The thematic map clearly states that the number of breeding sites increases with proportion to the human population. Highest number of mosquito breeding sites was recorded in the regions with high human population. The finding states that there is a significant relationship $[\mathrm{P}<0.005$; degree of freedom $(\mathrm{df})=2$ ] between mosquito breeding sites and human population density.

Number of breeding sites in comparison with the percentage of education of the people in the study area is pictured and presented in Figure 9. Regions like Idikarai, Kurichi, Narasimhanaichenpalayam, Periyanaichenpalayam and Saravanampatti with highest education rate reported both maximum and minimum number of breeding sites. Study plots exhibiting $73 \%$ to $75 \%$ of education reported 27,100 to 40,000 mosquito breeding sites/ $/ \mathrm{km}^{2}$; regions with $69 \%$ to $72 \%$ of education reported 21,800 to 27,000 -mosquito sites $/ \mathrm{km}^{2}$; regions with $56 \%$ to $68 \%$ of education reported 14,100 to 21,700 mosquito sites/ $\mathrm{km}^{2}$. From the present result it is evaluated that there is no significant relationship $(\mathrm{P}>0.5 ; \mathrm{df}=2)$ between education and breeding sites.

Figure 10 shows the comparative analysis of mosquito breeding sites with percentage of population aware of mosquitoes in the study area. The distribution pattern shows that both the lowest (14,100 mosquito breeding sites $/ \mathrm{km}^{2}$ ) and highest number (40,000 mosquito breeding sites $/ \mathrm{km}^{2}$ ) of breeding sites recorded in regions with $81 \%$ to $95 \%$ of population aware of mosquitoes. Moderate (21,800 to 27,000 mosquito sites $/ \mathrm{km}^{2}$ ) number of breeding sites recorded in regions with $80 \%$ and lesser population aware of mosquitoes. Though people aware of mosquitoes and mosquito-borne diseases the observed results states that there is no significant relationship $(\mathrm{P}>0.5 ; \mathrm{df}=2)$ between awareness and mosquito breeding sites.

Figure 11 shows the comparative analysis of mosquito density and mosquito breeding sites. Highest mosquito density (6/dip) recorded in four distribution patterns of mosquito breeding sites (18,106-21,786, $21,787-27,157,27,158-40,133,40,134-92,146$ number of breeding sites/sq. $\mathrm{km})$ out of five and the lowest mosquito density (2/dip) recorded in three distribution patterns of mosquito breeding sites $(14,238-18,105,18,106$ $21,786,27,158-40,133$ number of breeding sites/sq. km).

\section{Discussion}

Mosquitoes are responsible for serious public health problems all over the world. Mosquito control is relatively a challenging issue in all developing countries due to population growth, urbanisation, afforestation, resistant lineages development, etc. Management of diseases caused by vectors using synthetic chemicals has partially failed because of insurgence of insecticide resistance, vector resurgence, etc. Hence, novel techniques are requested to control mosquito menace (Wondji et al., 2009; Nareshkumar et al., 2013).

Sampling, counting and modelling the mosquito population accomplishes a number of things. It helps in determining the plan of mosquito control, knowing the growth stage of mosquitoes provides information necessary to time control methods. It tells which mosquito species are present, especially important in areas of disease outbreaks. Finally, it helps to gauge how effective control efforts have been and when they need to be employed again. The most effective ways to control a mosquito population is to reduce its larval (breeding) habitats. 
Human population density has a great impact on the distribution of mosquitoes. The industrial revolution is responsible of environmental pollution with the introduction of contaminants that cause instability, disorder, harm or discomfort to the ecosystem both in its physical and biotic components. The stressed ecosystems generally favour the development of opportunistic noxious species as mosquitos are.

Thematic maps can summarise the environmental risks including overpopulation in the world. The present study gives information about human population in the study area, high population density makes the main source of mosquito breeding sites. Muturi et al.

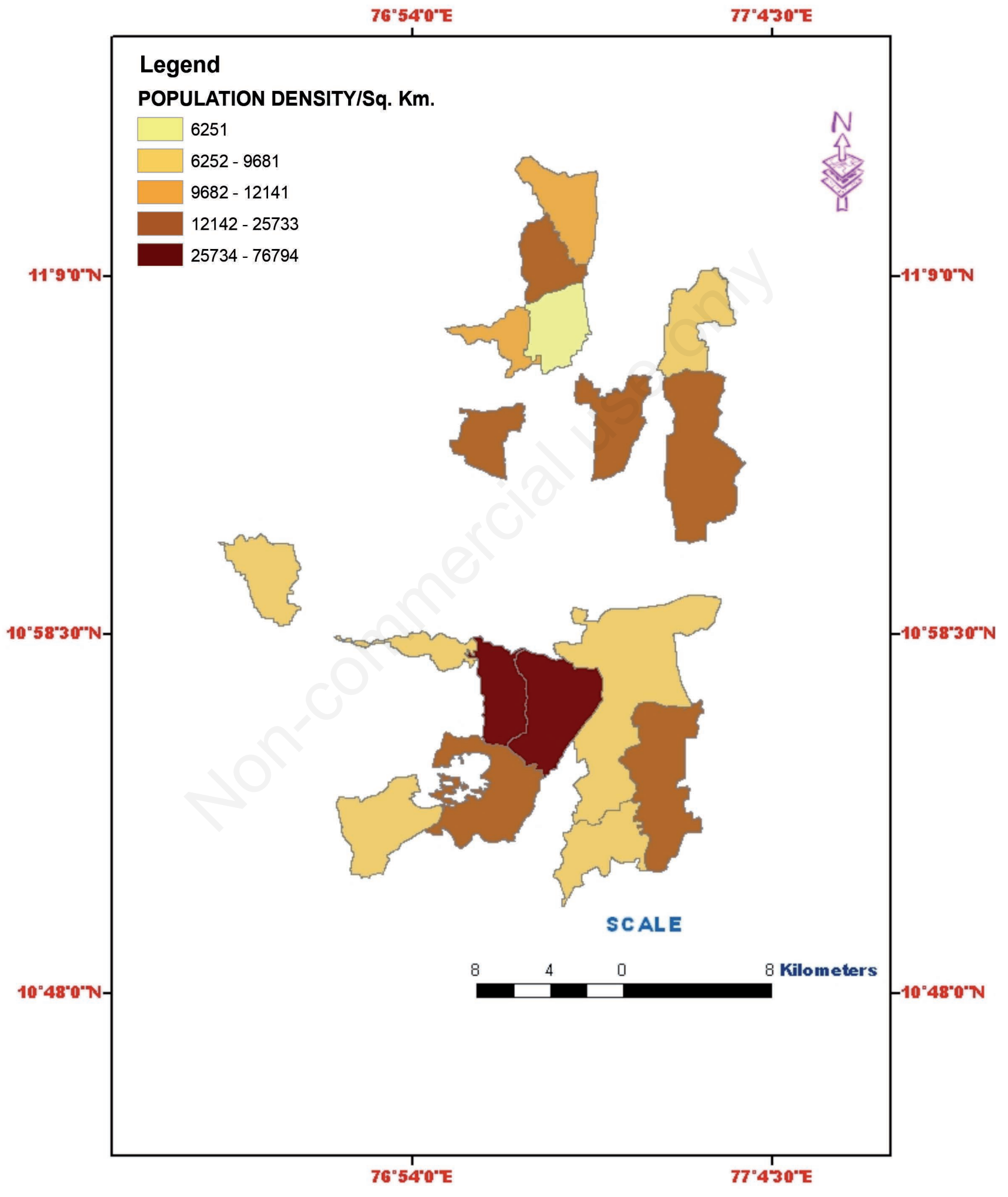

Figure 2. Distribution of human population in each village. 
(2008) conducted a 12-month entomological survey to determine the diversity of riceland mosquitoes and factors affecting their occurrence and distribution in 3 sites targeted for malaria vector control in Mwea (Kenya) and reported that there was a marked house-tohouse variation in the average number of mosquitoes captured.
Population in the house at nights preceding mosquito collection, size of eaves, distance to the cowshed, and the nearest larval habitat were significant predictors of occurrence of both An. arabiensis and $C$. quinquefasciatus, this observation is in concordance with the present study.

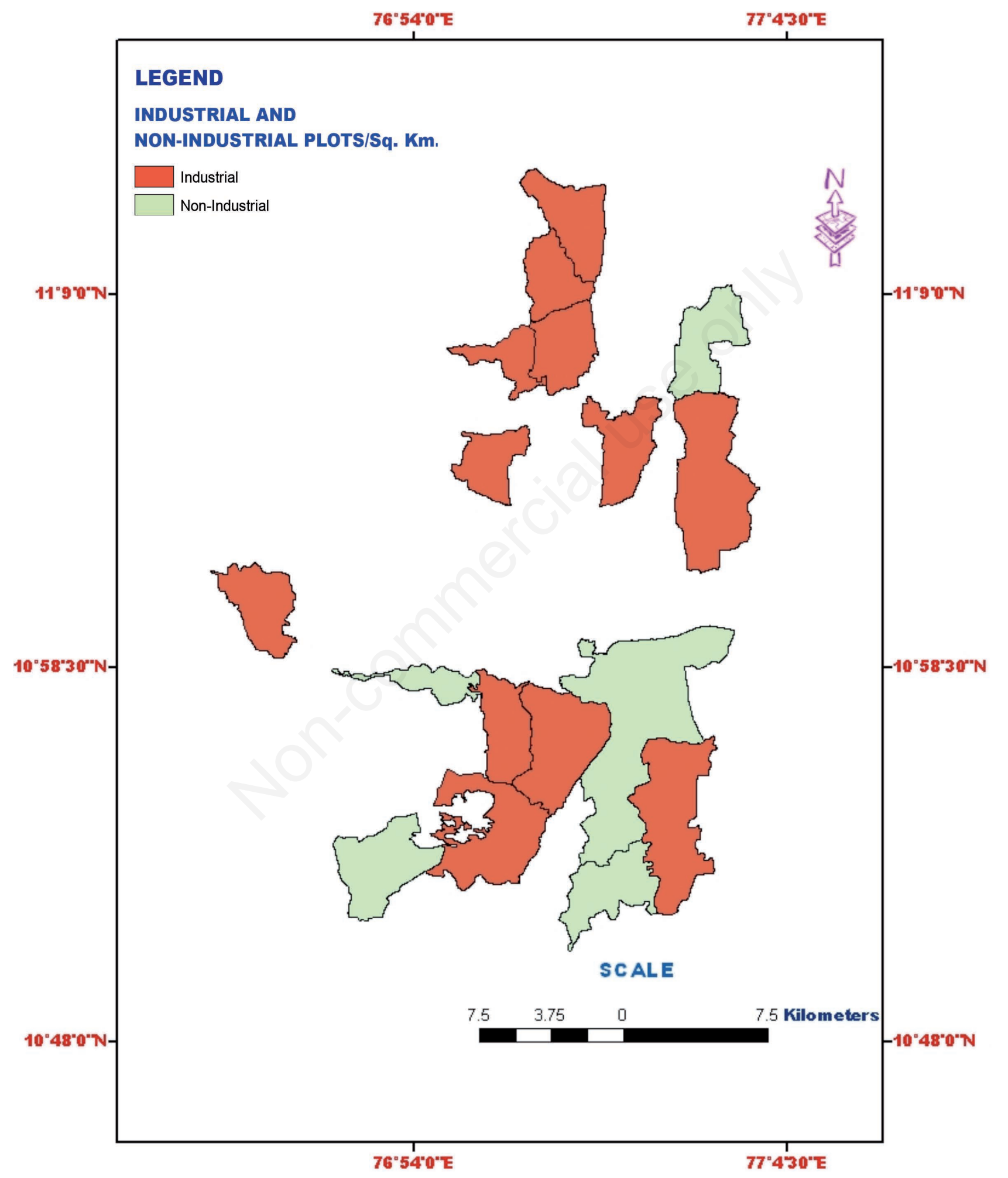

Figure 3. Industrial and non-industrial regions of the study plot. 
Industrialisation directly or indirectly influences the distribution of mosquitoes. In Africa, where 90\% of malaria cases are diagnosed, malaria parasites have followed the movements of humans into the industrialising cities (World Health Organisation, 2000).

The factors that affect the development of mosquitoes are high in rural areas. One of the important factors may be mosquito predators. In rural areas there is a tremendous diversity of predators that prey on the aquatic mosquito larvae, reducing mosquito survivorship (Andis \& Meek, 1985; Carlson et al., 2004). Industrialisation removes the favourable conditions for the development of predators, thus mos-

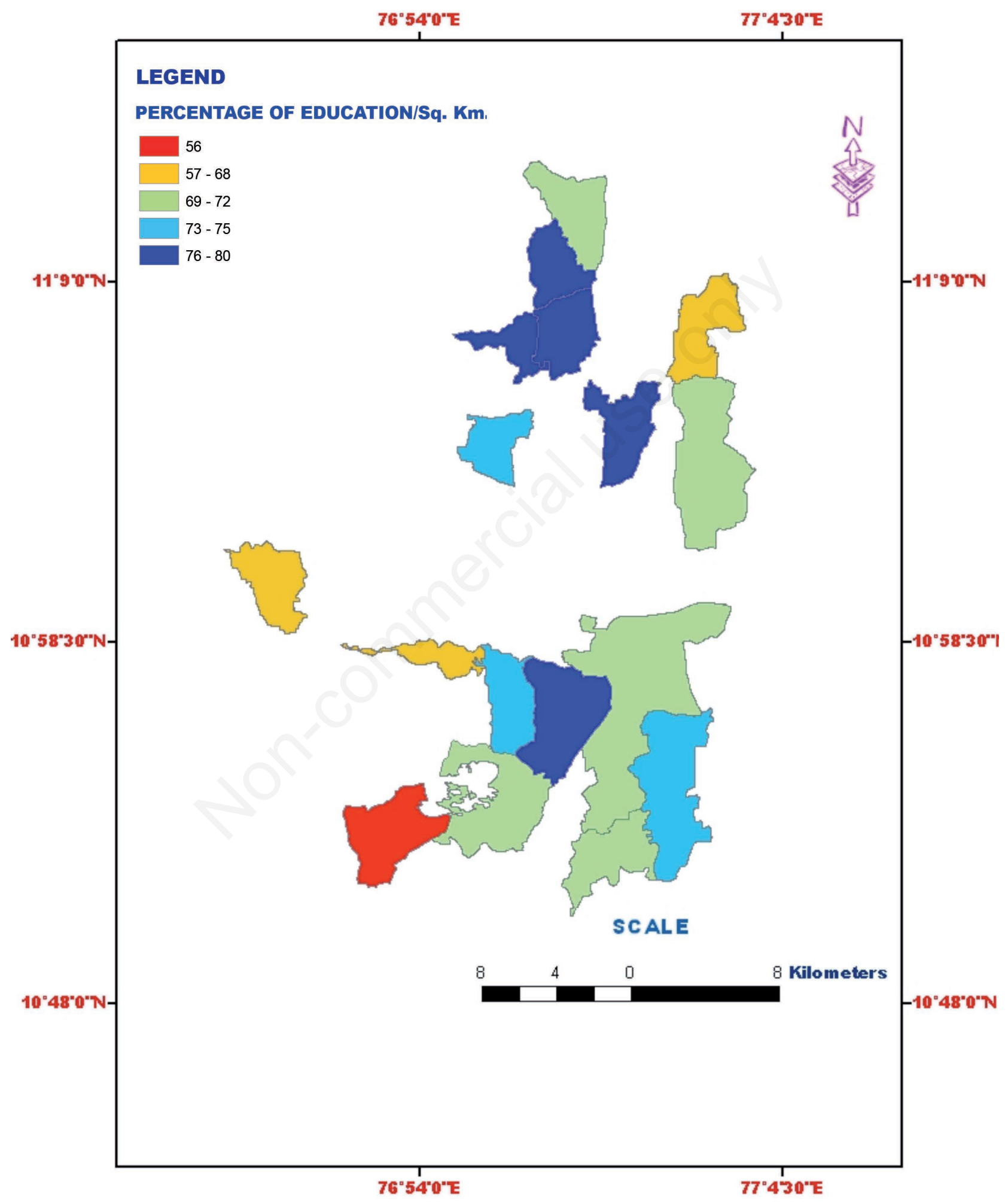

Figure 4. Level of education in each village. 
quitoes able to inhabit urban environments may benefit from diminished predation pressure.

The level of education has also an high impact on mosquitoes' developmental sites. Carrington (2001) stated that there should be mass campaigns for education training in controlling mosquito borne dis- eases. Knowledge on diseases and vector developments will assist populations to remove the developmental sites in and around their dwellings. People must be encouraged to help control mosquitoes through backyard source reduction. People need to be advised on where mosquitoes breed in their backyards. Advertisements, banners, media,

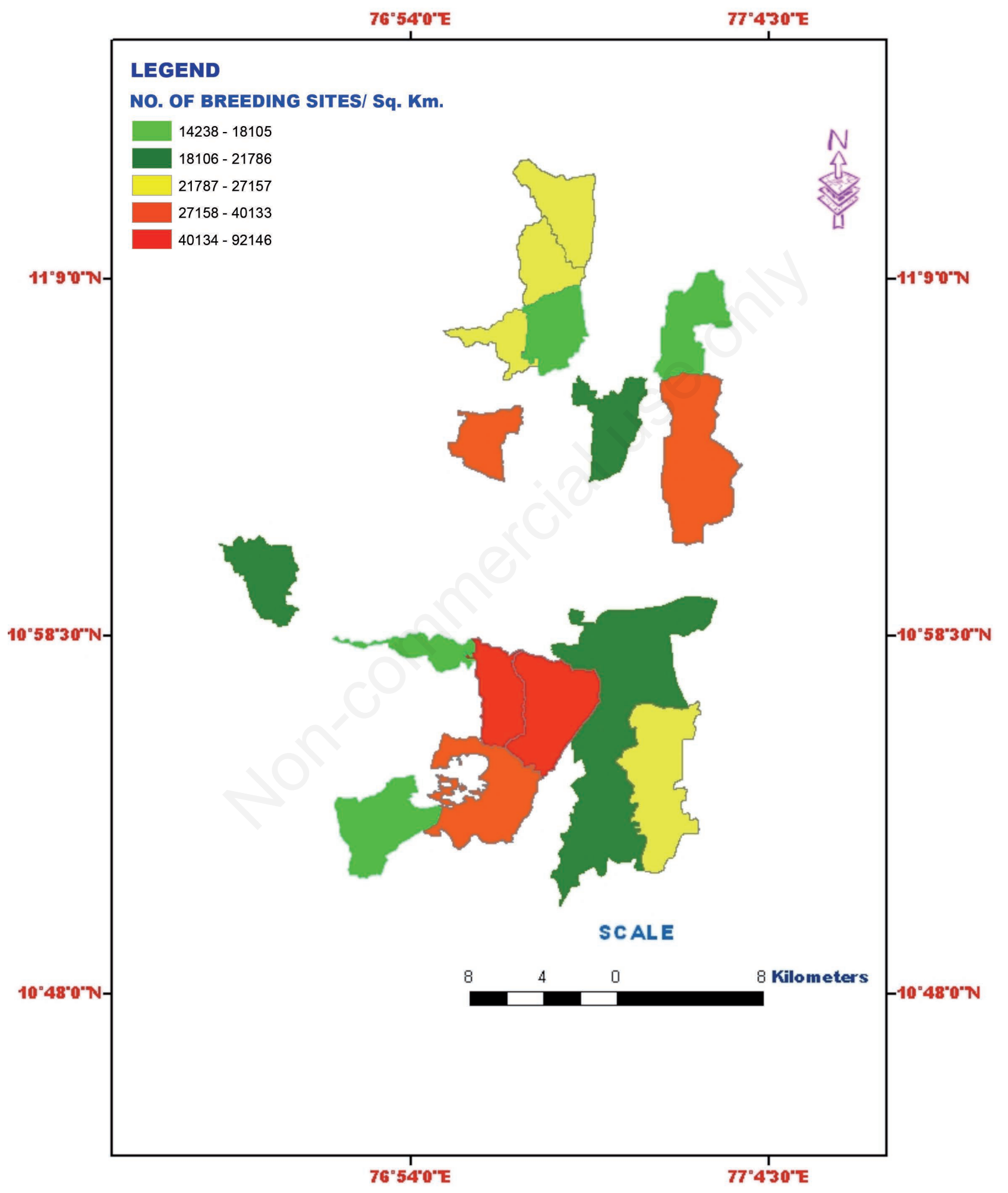

Figure 5. Number of breeding sites in each village. 
dramas and live programs on vector mosquitoes and their developmental sites can all be employed to create awareness among public in controlling the mosquito population.

Distribution of Culex in the present study affirmed that $C$. quinquefasciatus is predominant in the entire focal area, which explains the behavioural response and capability of the species in varied zones. $C$. tritaeniorhynchus, the primary vector of Japanese encephalitis, is predominant in industrial and agricultural regions, whereas distribution of $C$. gelidus is recorded in only one village, which was occupied by agricultural activities. $C$. quinquefasciatus occurs throughout the

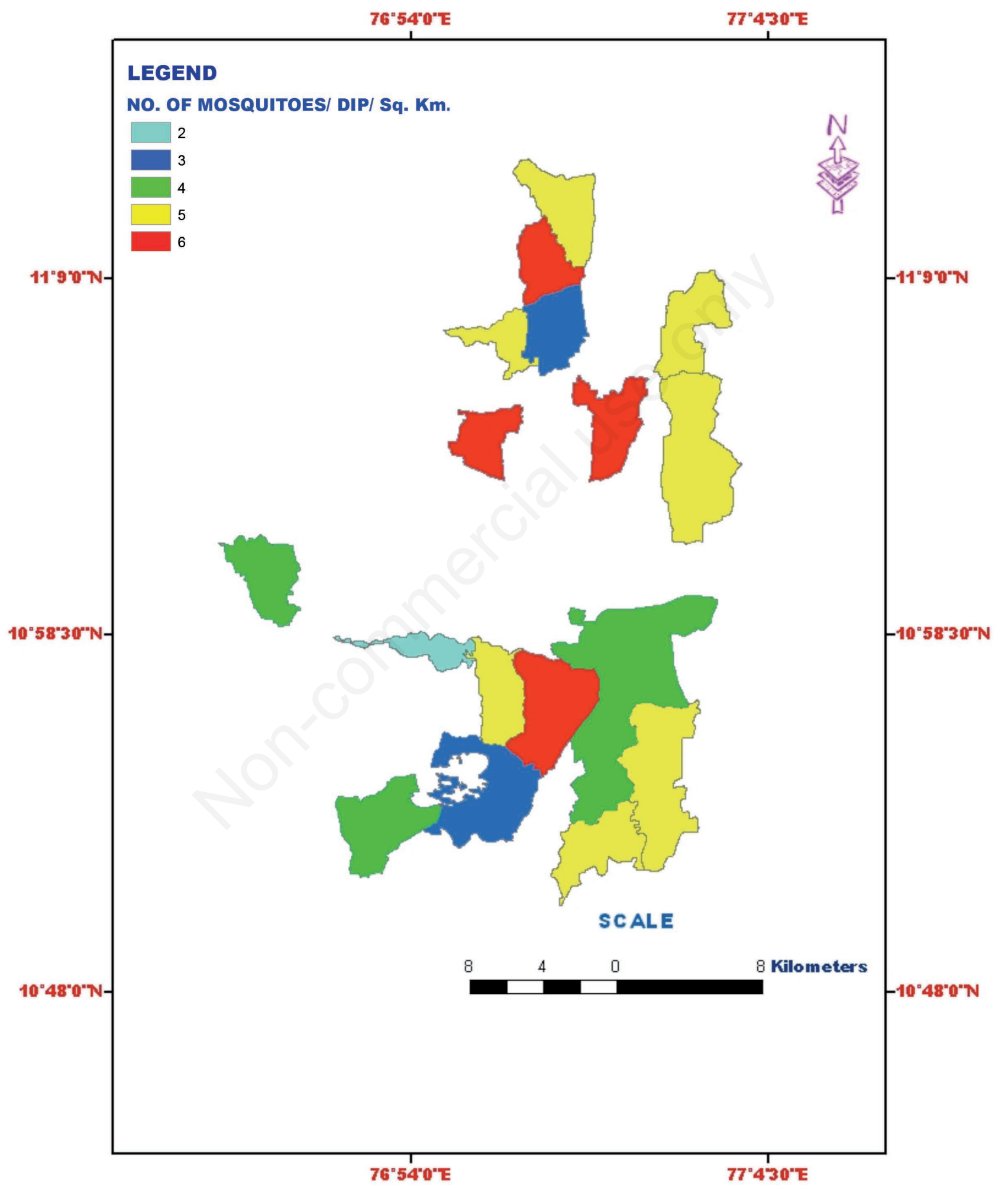

Figure 6. Number of immature mosquitos recorded in each village. 
tropic and subtropics of the world (Mattingly, 1951; Laven, 1967). In another study (Almirón et al., 1995) C. quinquefasciatus was the only species observed in the northern localities of Castelli and Esperanza. A precentage of $95.3 \%$ of species were $C$. quinquefasciatus in Argentina, which states the capability of the species to distribute themselves in varied environmental and climatic zones. Breeding sites of $C$. tritaeniorhynchus were nursery paddy beds, paddy fields and other large water bodies in the Idikarai, Saravanampatti, Thudiyalur, Veerapandi, Ettimadai, Madukkarai, Mallumichempatty, Othakalmandapam, Perur, and Thondamuthur,

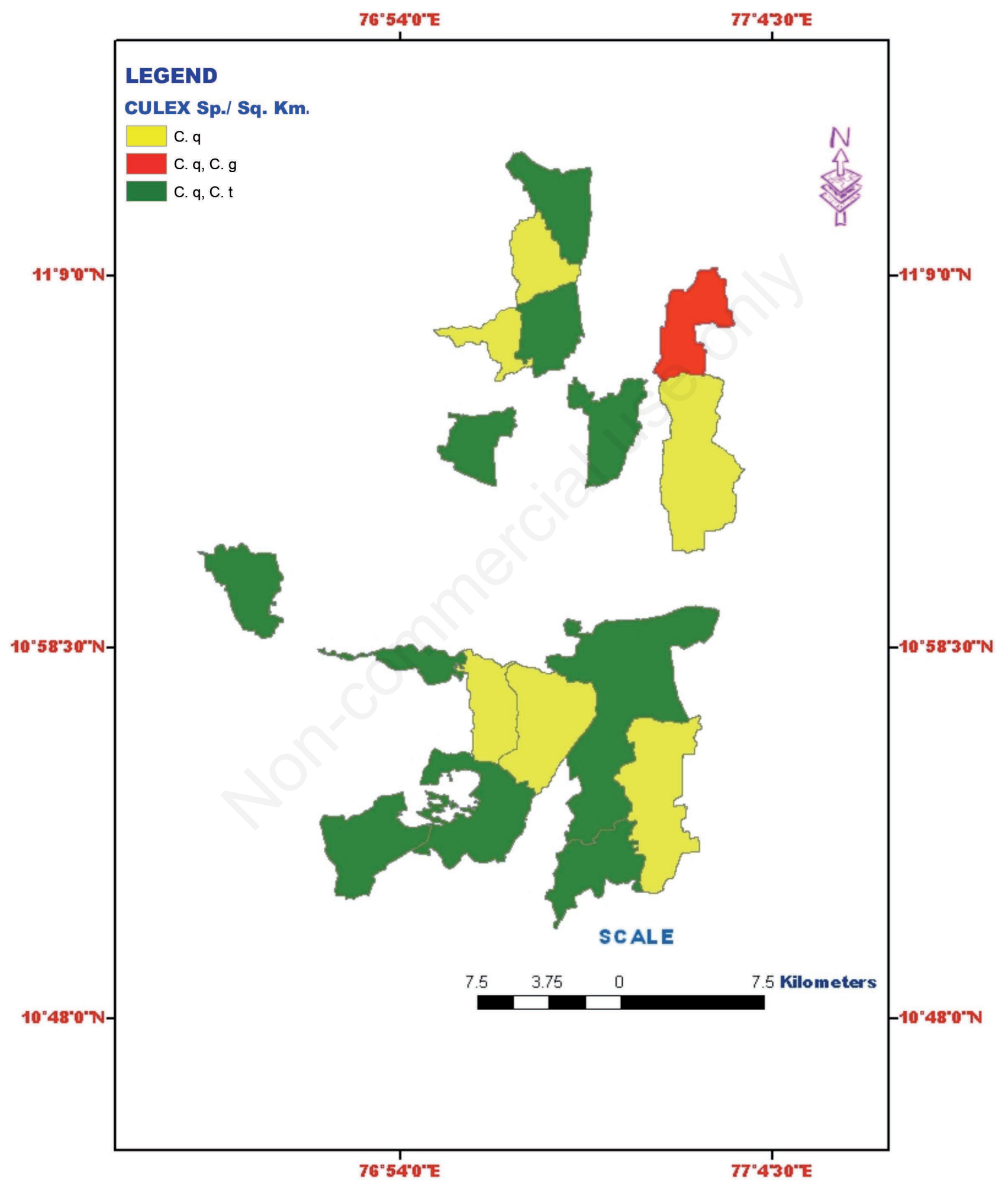

Figure 7. Distribution of Culex spp. larvae in each village. 
which contributed to increase $C$. tritaeniorhynchus adult densities in the study area. A similar result was observed earlier at Pusan, Sintaein, and Seoul (Self et al., 1973). Further as a support, earlier report on mosquito collections conducted in selected study areas (rural and urban) of Kurnool district, Andhra Pradesh, India to recognise the sea- sonal prevalence of JE vectors. Out of all the prevailing mosquito species, C. gelidus, C. tritaeniorhynchus, C. quinquefasciatus and An. subpictus were found to be the most common in these areas (Murty et al., 2010).

C. gelidus has a wide distribution throughout Asia, where it is a

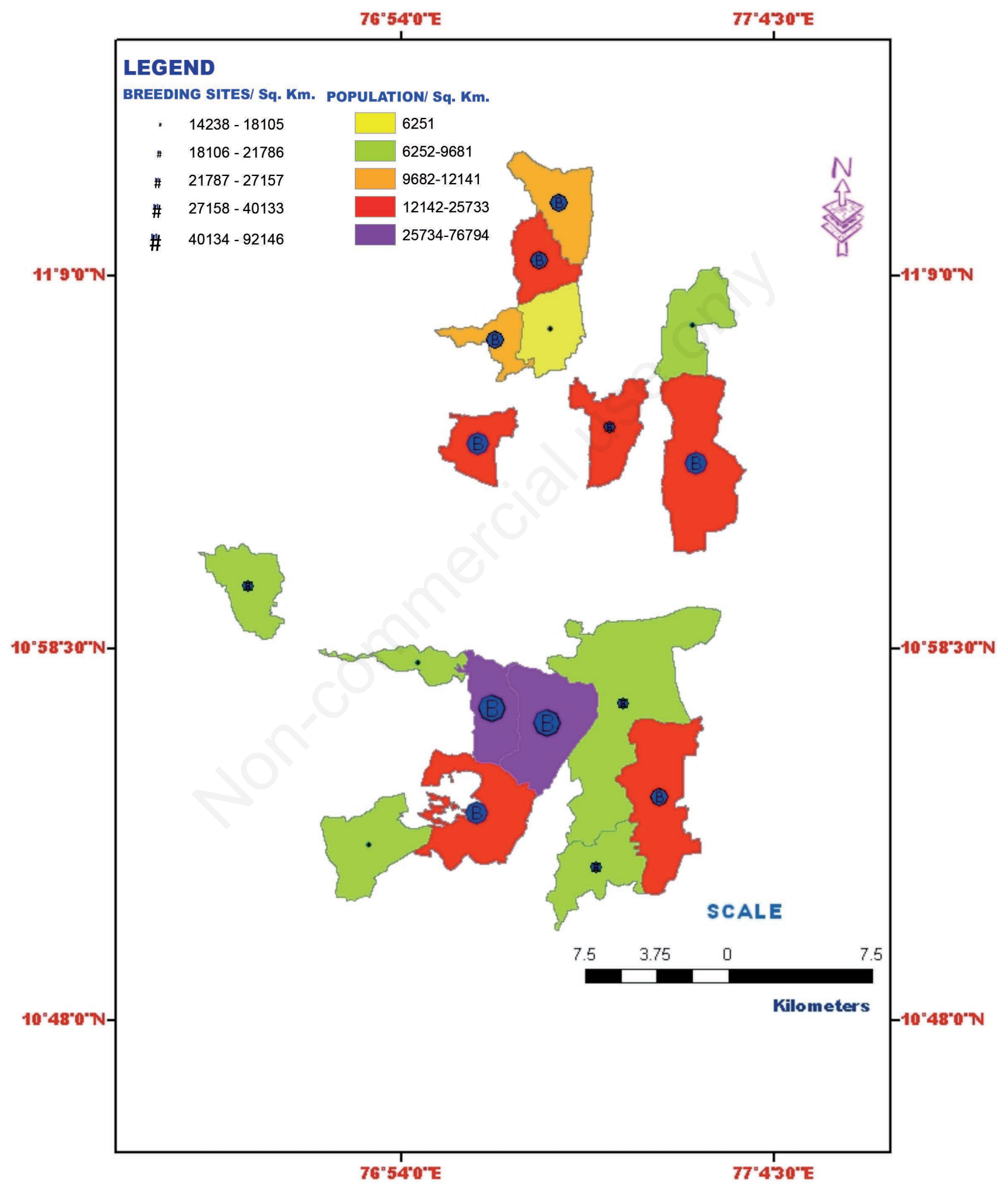

Figure 8. Association of human population with estimated number of mosquito sites in each village. 
vector of Japanese encephalitis. It was first detected in Australia in 1999 (Williams et al., 2005). The environmental and eco-climatic factors are assisting in enhancing the breeding of $C$. tritaeniorhynchus and $C$. gelidus mosquitoes in Kurnool district of Andhra Pradesh, India. Both $C$. tritaeniorhynchus and $C$. gelidus are quite adaptable to all environmental conditions and this necessitates immediate control measures in both rural and urban areas (Murty et al., 2010).

C. tritaeniorhynchus and $C$. gelidus population curves reached peaks just before the peak of the epidemic, but their distribution in Bangkok did not appear to be related to the haemorrhagic fever case-

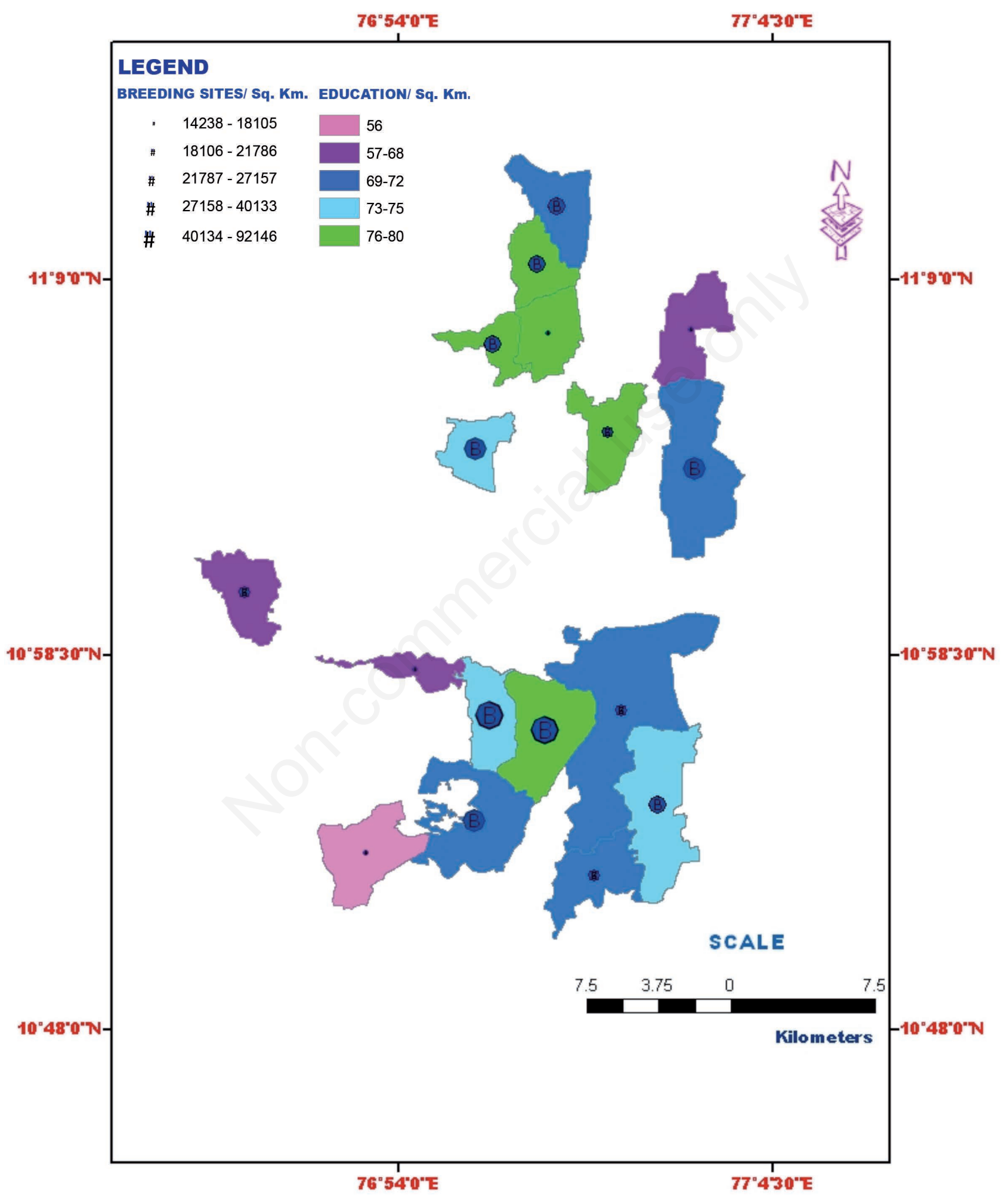

Figure 9. Association of education level with the estimated amount of mosquito breeding sites in each village. 
distribution. They were almost entirely rural in distribution, and much more strongly attracted to domestic animals than to man (Scanlon, 1963). Multivariate analyses revealed that the $C$. gelidus density correlated positively with both the host proximity to the breeding sites and cattle density (Hasegawa et al., 2008).

\section{Conclusions}

According to the present results it is clear that the distribution of Culex spp. is influenced by the human population and activity. The

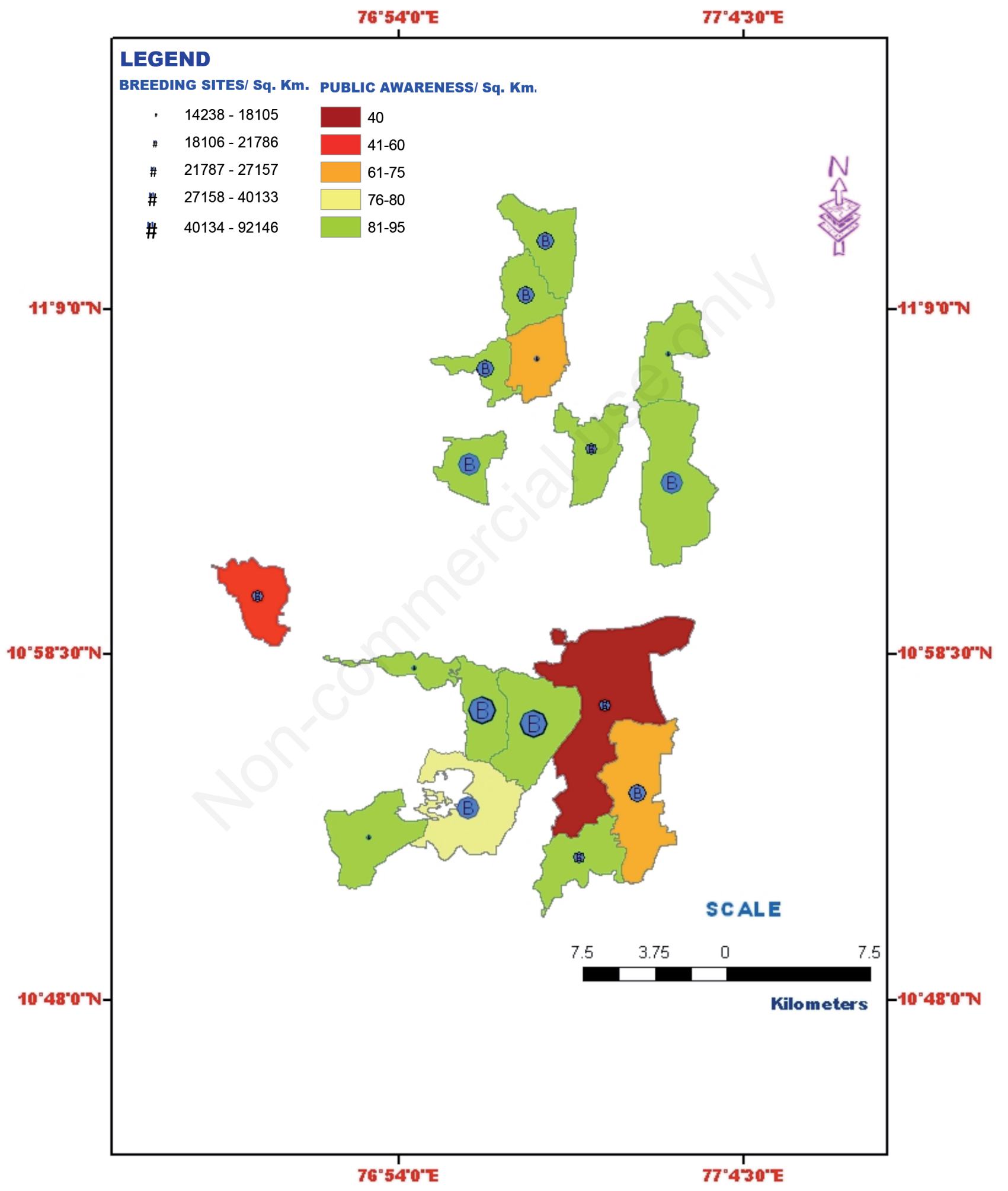

Figure 10. Association of public awareness with mosquito breeding sites in each village. 
present surveillance study emphasises that human population and industrialisation are the main causes of the increased numbers of mosquito breeding sites and mosquitoes. The study concludes that GIS is a novel cost and time effective technique use to predict factors responsible for development of mosquitoes and their breeding sites.
The study also maps out the endemic regions, which are to be taken care for immediate control measures.

The output is laymen friendly modelled and reaches the public with more interest. This study also stresses the importance of mosquito control measures.

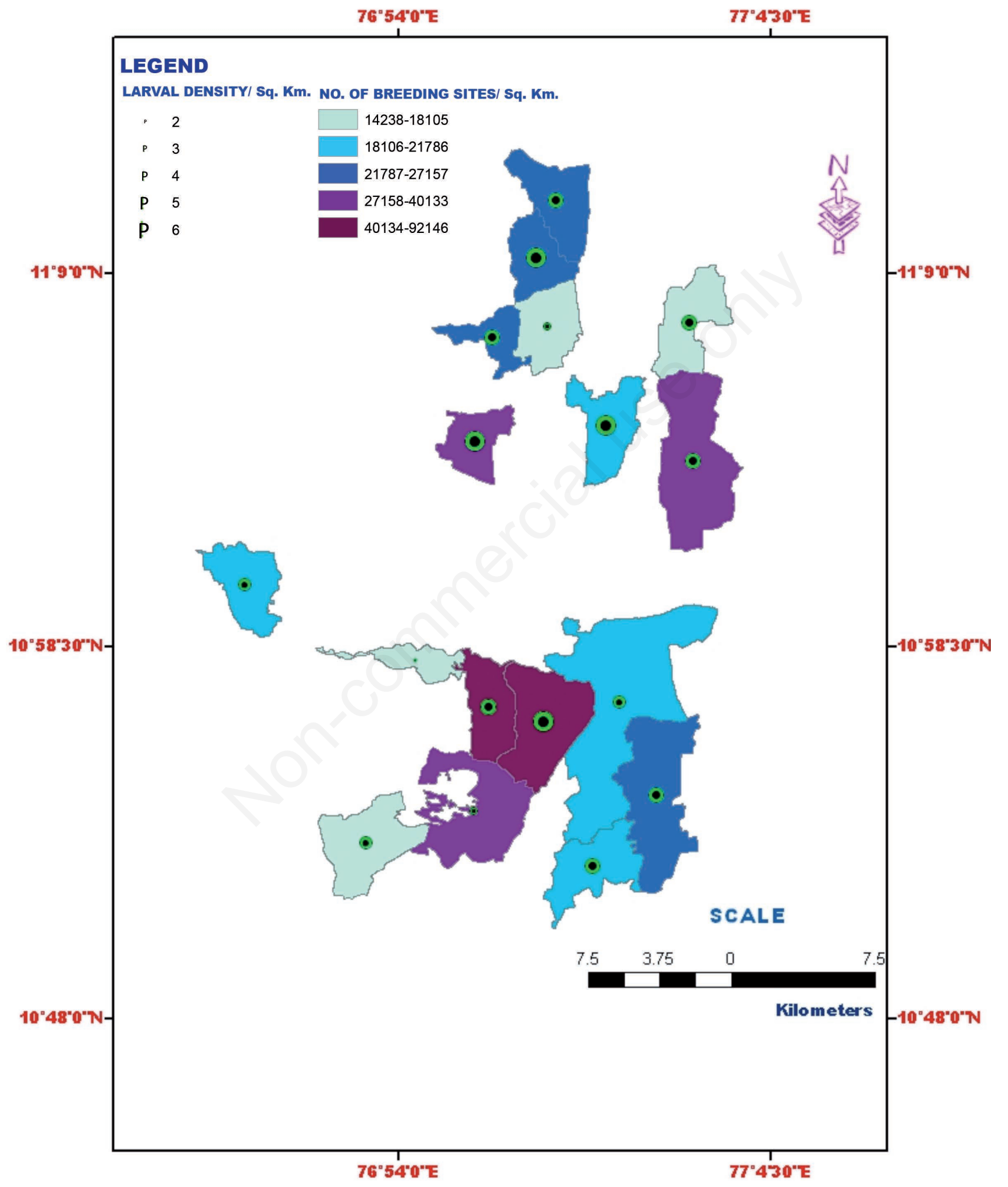

Figure 11. Association of mosquito breeding sites with immature mosquito density in each village. 


\section{References}

ALMIRÓN W.R., HUMERES S.G., GARDENAL C.N., 1995 - Distribution and hybridization between Culex pipiens and Culex quinquefasciatus (Diptera: Culicidae) in Argentina. - Mem. Inst. Oswaldo Cruz. 90: 469-473.

ANDIS M.D., MEEK C.L., 1985 - Mortality and survival patterns for the immature stages of Psorophora columbiae. - J. Am. Mosq. Contr Assoc. 1: 357-362.

CARLSON J., KEATING J., MBOGO C.M., KAHINDI S., BEIER J.C., 2004 - Ecological limitations on aquatic mosquito predator colonization in the urban environment. - J. Vector Ecol. 29: 331-339.

CARRINGTON A., 2001 - Malaria: its human impact, challenges, and control strategies in Nigeria. - Harvard Health Policy Rev. 2: 1-3.

DALE P.E., MORRIS C.D., 1996 - Culex annulirostris breeding sites in urban areas: using remote sensing and digital image analysis to develop a rapid predictor of potential breeding areas. - J. Am. Mosq. Control Assoc. 12: 316-320.

GINGRICH J.B., NISALAK A., LATENDRESSE J.R., SATTABONGKOT J., HOKE C.H., POMSDHIT J., CHANTALAKANA C., SATAYAPHANTA C., UECHIEWCHARNKIT K., INNIS B.L., 1992 - Japanese encephalitis virus in Bangkok: factors influencing vectors infections in three suburban communities. - J. Med. Entomol. 29: 436-444.

HASEGAWA H., LIND E.J., BOIN M.A., HASE C.C., 2008 - The extracellular metalloprotease of Vibrio tubiashii is a major virulence factor for Pacific oyster (Crassostre agigas) larvae. - Appl. Environ. Microbiol. 74: 4101-4110.

LAVEN H., 1967 - Speciation and evolution in Culex pipiens. In: J. WRIGHT, R. PAL (Eds.), Genetics of insect vectors of disease. Elsevier, Amsterdam, the Netherlands, 7: 251-275.

LIN T.H., LU L.C., 1995 - Population fluctuation of Culex tritaeniorhynchus in Taiwan. - Chinese J. Entomol. 15: 1-9.

LINTHICUM K.J., BAILEY C.L., DAVIES F.G.,TUCKER C.J., 1987 Detection of Rift Valley fever viral activity in Kenya by satellite remote sensing imagery. - Science. 235: 1656-1659.

MASUOKA P.M.,CLABORN D.M., ANDRE R.G., NIGRO J., GORDON S.W., KLEIN T.A., KIM H., 2003 - Use of IKONOS and Landsat for malaria control in the Republic of Korea. - Remote Sensing Environ. 88: 187-194.

MATTINGLY P.F., 1951 - Culex torrentium Martini, a mosquito new to Great Britain. - Nature Lond. 168: 172.

MURTY U.S., RAO M.S., ARUNACHALAM N., 2010 - The effects of cli- matic factors on the distribution and abundance of Japanese encephalitis vectors in Kurnool district of Andhra Pradesh, India. J. Vector Borne Dis.47: 26-32.

MUTURI E.J., SHILILU J.I., JACOB B.G., MWANGANGI J.M., MBOG0 C.M., GITHURE J.I., NOVAK R.J., 2008 - Diversity of riceland mosquitoes and factors affecting their occurrence and distribution in Mwea, Kenya. - J. Am. Mosq. Control Assoc. 24: 349-358.

NARESHKUMAR A., JEYALALITHA T., MURUGAN K., MADHIYAZHAGAN P., 2013 - Bioefficacy of plant-mediated gold nanoparticles and Anthocepholus cadamba on filarial vector, Culex quinquefasciatus (Insecta: Diptera: Culicidae). - Parasitol. Res. 112:1053-1063.

POPE C.A., SCHWARTZ J., ANSOMS M.R., 1992 - Daily mortality and PM 10 pollution in the Utah valley. - Arch. Environ. Health. 47: 211-217.

SCANLON J.E., 1963 - Bangkok haemorrhagic fever investigations: the 1962-63 mosquito collections. Originally issued as document IR/Haem.Fever/Sem. 1/WP/20. - Abreges Des Communications, pp. 82-83.

SELF L.S., SHIN H.K., KIM K.H., LEE K.W., CHOW C.Y., HONG H.K., 1973 - Ecological studies on Culex tritaeniorhynchus as a vector of Japanese encephalitis. - Bull. Orgmond. Santé; Bull. World Health Org. 49: 41-47.

THOMSON M.C., CONNOR S.J., MILLIGAN P.J.M., FLASSE S.P., 1996 The ecology of malaria as seen from Earth observation satellites. Ann. Trop. Med. Parasitol. 90: 243-264.

WILLIAMS C.R., RITCHIE S.A., WHELAN., 2005. Potential distribution of the Asian disease vector Culex gelidus Theobald (Diptera: Culicidae) in Australia and New Zealand: a prediction based on climate suitability. - Aust. J. Entomol. 44: 425-430.

WONDJI C.S., IRVING H., MORGAN J., LOBO N.F., COLLINS F.H., HUNT R.H., COETZEE M., HEMINGWAY J., RANSON H., 2009 - Two duplicated P450 genes are associated with pyrethroid resistance in Anopheles funestus, a major malaria vector. - Genome Res. 19:452-459.

WOOD B.L., BECK L.R., WASHINO R.K., HIBBARD K., SALUTE J.S., 1992 - Estimating high mosquito-producing rice fields using spectral and spatial data. - Int. J. Remote Sens. 13: 2813-2826.

WORLD HEALTH ORGANISATION, 2000 - WHO Expert Committee on Malaria. - WHO Tech. Rep. Ser. 892: i-v, 1-74.

WORLD HEALTH ORGANISATION, 2013 - Lymphatic filariasis, epidemiology, the vector. - Available from: http://www.who.int/lymphatic_ filariasis/epidemiology/en/

ZOU L., MILLER S.N., SCHMIDTMAN N., 2006 - Mosquito larval habitat mapping using remote sensing and GIS: Implication of Coalbed Methane development and West Nile Virus. - J. Med. Entomol. 43: 1034-1041. 